\title{
Distinguishing resistances of transgenic sugarcane generated from RNA interference and pathogen-derived resistance approaches to combating sugarcane mosaic virus
}

\author{
Weny Nailul Hidayati ${ }^{1}$, Retnosari Apriasti ${ }^{2}$, Hardian Susilo Addy ${ }^{3}$, Bambang Sugiharto ${ }^{2,4,}$ \\ ${ }^{1}$ Post Graduate Program for Biotechnology, University of Jember, J. Kalimantan No.37, Jember 68121, Indonesia \\ ${ }^{2}$ Center for Development of Advanced Sciences and Technology (CDAST), University of Jember, Jl. Kalimantan No.37, Jember 68121, \\ Indonesia \\ ${ }^{3}$ Faculty of Agriculture,University of Jember, Jl. Kalimantan No. 37, Jember 68121, Indonesia \\ ${ }^{4}$ Biology Department, University of Jember, Jl. Kalimantan No.37, Jember 68121, Indonesia \\ ${ }^{*}$ Corresponding author: sugiharto.fmipa@unej.ac.id
}

SUBMITTED 16 March 2021 REVISED 10 May 2021 ACCEPTED 18 May 2021

\begin{abstract}
Sugarcane mosaic virus (SCMV) is a causative agent that reduces growth and productivity in sugarcane. Pathogen-derived resistance (PDR) and RNA interference (RNAi) are the most common approaches to generating resistance against plant viruses. Two types of transgenic sugarcane have been obtained by PDR and RNAi methods using a gene-encoding coat protein (CP) of SCMV (SCMVCp). This research aimed to distinguish resistance of the two transgenic sugarcanes in combating SCMV through artificial viral inoculation. The experiment was conducted using transgenic sugarcane lines validated by PCR analysis. Insertion of gene-encoding CP in the transgenic lines was confirmed by amplification of $702 \mathrm{bp}$ of DNA fragment of SCMVCp. After viral inoculation, mosaic symptoms appeared earlier, at 21 days post inoculation (dpi) in PDR transgenic lines, but was at 26 dpi in RNAi transgenic lines. Symptom observation showed that $77.8 \%$ and $50 \%$ of the inoculated plants developed mosaic symptoms in PDR and RNAi transgenic lines, respectively. RT-PCR analysis revealed that the nuclear inclusion protein b (Nib) gene of SCMV was amplified in the symptomatic leaves in plants classified as susceptible lines. Immunoblot analysis confirmed presence of viral CP with a molecular size of $37 \mathrm{kDa}$ in the susceptible lines. Collectively, these results indicated that the RNAi approach targeting the gene for $\mathrm{CP}$ effectively produces more resistance against the SCMV infection in transgenic sugarcane compared to the PDR approach.
\end{abstract}

KEYWORDS Sugarcane mosaic virus (SCMV; pathogen-derived resistance; RNA interference; viral resistance; transgenic sugarcane

\section{Introduction}

Sugarcane (Saccharum officinarum L.) is an important agricultural commodity for sugar production in Indonesia. The productivity of sugarcane was affected by several factors, such as topography, climate, soil fertility, insects, fungal, bacterial, and viral infections (Srivastava 2012). Sugarcane mosaic virus (SCMV) is one of the most destructive viruses for sugarcane in Indonesia with disease incidence up to 78\% (Addy et al. 2017) and reduce yield up to $45 \%$ (Kumar P 2013). The SCMV infection inhibits the development of stem diameter and length of internode from the early growth to the harvest period. The impact of viral infection could be attributed to disturbance of gene expression associated with the photosynthesis process (Chen et al. 2017a) and chlorosis on sugarcane leaves showing mosaic patterns. In addition, upon infection in host plants, the virus is distributed from cell to cell using plasmodesmata, then the virus moves from source to sink tissue through the vascular system to establish systemic infection (Anurag 2013).

SCMV belongs to the genus of Potyvirus, the family of Potyviridae, which has a positive-sense single-stranded RNA (+ssRNA) genome type. The genome has an open reading frame (ORF) encoding 10 proteins, such as $\mathrm{P} 1$, HC-pro, P3, 6K1, CI, 6K2, NIa-VPg, NIa-pro, NIb, and CP (Gao et al. 2011). In plants, Potyvirus is transmitted by vector-like aphids during the feeding process via stylets. The virus transmission occurs through two different strategies, in the capsid strategy, coat protein (CP) directly interacts with binding sites (receptors) in the aphid stylet. While, in the helper strategy, non-structural protein HCPro (Helper component proteinase) facilitates the binding by creating a reversible molecular bridge between $\mathrm{CP}$ and aphid receptors (Gadhave et al. 2020). Thus, the CP is the 
widely studied infection of the virus at a molecular level in plants.

$\mathrm{CP}$ plays a role in the systemic spread of viruses in plant tissues and regulates the assembly process of intact virus particles (Besong-Ndika et al. 2015). CP was known to provide resistance to protect from Tobacco mosaic virus (TMV) infection in transgenic tobacco through the CPmediated resistance (CP-MR) technique. This technique induces resistance when the Cp gene was expressed in plant cells and forms an aggregate of CP (Sharma et al. 2020). Transgenic tobacco that expressing the CP has been shown to inhibit TMV virus infection by interfering with the accumulation of movement protein (MP) responsible for carrying viral particles from cell to cell and blocking the virus particle assembly (Bendahmane et al. 2002). The expressing CP could prevent TMV virions from undergoing co-translational disassembly, which is an early event of infection. The protective mechanism of transgenic CP is immediately recoated disassembling virus particles to prevent their infection (Lu et al. 1998). Resistance against virus using CP was also successfully performed in peanuts (Arachis hypogea L.) (Mehta et al. 2013), in eggplant (Solanum melongea L.) (Pratap et al. 2011), and sugarcane (Saccharum officinarum L.) (Apriasti et al. 2018). The defense against viruses through the expression of nucleotide sequences derived from viruses to produce the viral protein in plant cell is known as pathogen-derived resistance (PDR) (Lindbo and Dougherty 1992; Sharma et al. 2020).

RNA interference (RNAi) or RNA silencing is also known as a defense mechanism that protects plants from pathogen infections and down-regulate the viral gene expression in a specific manner (Muhammad et al. 2019). Transgenic RNAi has been developed as a molecular tool for enhancing disease resistance in plants. The resistance mechanism of RNAi has effectively synthesized smallinterfering RNA (siRNA) to down-regulate toxic fungal genes in Aspergillus and Fusarium fungi based on the formation of hairpin RNA (hpRNA) to control mycotoxigenic fungi (Majumdar et al. 2017). The dsRNA or hpRNA is processed into small interfering RNA (siRNAs) of 2128 nucleotide in lenght by the activity of RNase III-like enzymes called Dicer. The siRNAs bind to argonaute (AGO) a ribonuclease $\mathrm{H}$-like protein, then incorporate into a RNA-induced silencing complex (RISC) (Widyaningrum et al. 2021). Small RNA complexes could recognize RNA targets through complementary base pairs, while the AGO protein functions as an effector to modulate target activity (Campo et al. 2016). Therefore, the RNAi resistance mechanism has a high efficiency that suppresses viral infection through dsRNA expression in the transgenic plant by targeting the Cp gene in Plum pox virus (Montes et al. 2014). Recently, the RNAi mechanism has been proven workable to combat virus infection in transgenic sugarcane (Widyaningrum et al. 2021).

The transgenic sugarcane resistance to SCMV has been successfully produced by the PDR (Apriasti et al. 2018) and RNAi (Widyaningrum et al. 2021) approach targeting the coat protein (Cp) gene of SCMV. In this research, we compared the two types of transgenic sugarcane lines and determined the level of effectiveness in preventing SCMV infection through the viral challenge. The results showed that RNAi more effective to combat the virus infection compared to the PDR technique. This is the first report for the comparative study of the response SCMV infection of two different transgenic sugarcane generated by the PDR and RNAi approach.

\section{Materials and Methods}

\subsection{Transgenic sugarcane plant materials}

To distinguish the resistances of transgenic sugarcane lines generated by PDR and RNAi methods, the transgenic lines were grown in the greenhouse. The lateral buds were isolated from previous T2 transgenic lines generated from both PDR (Apriasti et al. 2018) and RNAi (Widyaningrum et al. 2021), then germinated and cultured in the pot containing soil media. Totally three (A10, A11, A13) and four (C16, C18, U1, U8) transgenic lines generated from PDR and RNAi with three replicates were cultivated in a greenhouse for three months, respectively. The plants were subjected to artificial SCMV inoculation at the indicated time and observed the development of mosaic symptoms, followed by molecular analysis.

\subsection{Viral inoculation and mosaic symptom observation}

To determine the resistances against SCMV, six weeks cultured the transgenic lines were challenged with a viral inoculum prepared from the symptomatic sugarcane leaves infected by the virus. The virus inoculum was prepared as plant sap (plant fluid) according to the method previously described (Apriasti et al. 2018). Two grams of the sugarcane leaves were ground using a sterile mortar and pestle on ice, and added with $2 \%$ of polyvinylpyrrolidone (PVP). The crushed leaves were transferred into a falcon tube containing $20 \mathrm{ml}$ of $0.1 \mathrm{M}$ phosphate buffer $\mathrm{pH} 7.0$ and the solution was immediately used as inoculum. Before virus inoculation, the transgenic plants were incubated in dark conditions for a night. The virus inoculant was mechanically inoculated on leaves by carefully scratching the 2nd and 3rd of the youngest leaves using 600 mesh of carborundum, followed by rubbing the leaves with sap and stand for 5 min. The plant was rinsed using sterile distilled water to remove the remaining carborundum and sap liquid and then was continuously cultivated in the greenhouse.

The mosaic symptom was daily observed on the sugarcane leaves after the viral inoculation over $45 \mathrm{~d}$ postinoculation (dpi). The mosaic pattern on leaves was determined and grouped according to the Cobb scale (Kiss and Veres 2017). The number of symptomatic plants, including the incubation period, was recorded as previously described (Apriasti et al. 2018). Plant with or without symptoms was used for further molecular analysis. 


\subsection{DNA extraction and PCR analysis}

Genomic DNA of sugarcane was extracted from leaf tissue using the SDS protocol according to the method previously described (Widyaningrum et al. 2021). One g of the leaf tissue was ground using liquid nitrogen in a mortar and pestle, and the frozen leaf powder was added with 1 $\mathrm{mL}$ of extraction buffer containing $100 \mathrm{mM}$ Tris- $\mathrm{HCl}(\mathrm{pH}$ 8), 50 mM EDTA, $500 \mathrm{mM} \mathrm{NaCl}, 1 \%$ SDS, and $5 \mathrm{mM}$ 2mercaptoethanol and then incubated at $65^{\circ} \mathrm{C}$ for $10 \mathrm{~min}$. The mixture was centrifugated at $12,000 \times \mathrm{g}$ at $4{ }^{\circ} \mathrm{C}$ for 10 min and the supernatant was added with 0.8 vol. of isopropanol. After incubation at $-20^{\circ} \mathrm{C}$ for an hour, the DNA was collected by centrifugation and rinsed with $70 \%$ cold ethanol. The remaining ethanol was evaporated and DNA was dissolved in $20 \mu$ l of buffer containing $10 \mathrm{mM}$ Tris$\mathrm{HCl}$ (pH 7.5), 1 mM EDTA (TE buffer). The DNA concentration was determined by NanoVue spectrophotometer (GE Healthcare, UK) at $260 \mathrm{~nm}$ and stored at $-20{ }^{\circ} \mathrm{C}$ for analysis.

PCR analysis was conducted to confirm the insertion of the Cp gene in the transgenic lines. The PCR analysis was conducted using a master mix kit (GoTaq Green Master Mix, Promega, USA), $1 \mu \mathrm{g}$ DNA genome, and a primer pair of SCMVCp (F1-R1) according to the method previously described (Apriasti et al. 2018). The PCR amplification cycle was carried out using a T100 thermocycler (Bio-Rad, USA) with the condition of pre-denaturation at $95{ }^{\circ} \mathrm{C}$ for $5 \mathrm{~min}$, followed by the 35 cycles of denaturation at $95{ }^{\circ} \mathrm{C}$ for $30 \mathrm{~s}$, at $58{ }^{\circ} \mathrm{C}$ annealing for $30 \mathrm{~s}$, extension at $72{ }^{\circ} \mathrm{C}$ for $1 \mathrm{~min}$, and the final extension at $72{ }^{\circ} \mathrm{C}$ for 5 min. The PCR product was separated on $1 \%$ agarose gel electrophoresis and visualized using the GelDoc (Major Science, USA).

\subsection{Viral detection by RT-PCR and immunoblot analy- sis}

To detect viral infection RT-PCR analysis was conducted for amplification DNA fragment of Nib gene after the viral infection in sugarcane. Total RNA was extracted from 0.5 $\mathrm{g}$ of the sugarcane leaves using the RNAprep Pure Kit for plant (Tiangen, China). The isolated total RNA was then

TABLE 1 Oligonucleotide primers used in this study.

\begin{tabular}{llll}
\hline Primers & Sequence (5'-3') & Product (bp) & Target genes \\
\hline F1 & $\begin{array}{l}\text { CCC CAT ATG ACA GTC } \\
\text { GAT GCA GGT GCTC }\end{array}$ & 725 & ScMVCp \\
R1 & $\begin{array}{l}\text { ATG GAT CCT AGT GGT } \\
\text { GCT GCT GCA CTCCC }\end{array}$ & 725 & ScMVCp \\
F2 & $\begin{array}{l}\text { GCA ACT GGG ATG ACA } \\
\text { TGG AG }\end{array}$ & Actin \\
R2 & $\begin{array}{l}\text { ATG GCT GGA AGA GGA } \\
\text { CCT CAG }\end{array}$ & Actin \\
F3 & $\begin{array}{l}\text { GCC ATA CTC GAG TGG } \\
\text { GAT CG }\end{array}$ & 483 & Nib \\
R3 & $\begin{array}{l}\text { CCT TGT CTC TTT GGC } \\
\text { CTC CTG }\end{array}$ & 483 & Nib \\
\hline
\end{tabular}

dissolved into sterile dd $\mathrm{H}_{2} \mathrm{O}$ and measured the RNA concentration using a NanoVue spectrophotometer at a wavelength of $260 \mathrm{~nm}$ (GE Healthcare, USA). One $\mu \mathrm{g}$ of total RNA was converted into cDNA using reverse transcriptase and oligo-dT primer according to the manufacture protocol (Bio-Rad, USA). The cDNA was used as a template for PCR amplification of the Nib DNA fragment using a primer pair of F4-R4. To ensure the total isolated RNA has the same concentration, the Actin gene as an internal control was determined by employing a pair of F3-R3 primers (Table 1).

To confirm the viral infection, immunoblot analysis was conducted using a polyclonal antibody against CP (Darsono et al. 2018). The sugarcane leaves (2 g) were ground using liquid nitrogen, and the protein was extracted using a buffer containing $50 \mathrm{mM}$ of Tris-HCl (pH 7.5), 5 $\mathrm{mM}$ of EDTA, $1 \mathrm{mM}$ of phenylmethylsulfonyl fluoride, 10 $\mathrm{mM}$ of 2-mercaptoethanol, and 2\% polyvinylpolypyrrolidone (PVP). The mixture was centrifuged at a speed of $14,000 \times \mathrm{g}, 4^{\circ} \mathrm{C}$ for $10 \mathrm{~min}$. Insoluble protein was solubilized from the pellet using a buffer containing $50 \mathrm{mM}$ Tris-HCl (pH 8.5), 1 mM EDTA, 2\% SDS, and 30\% sucrose and separated using centrifugation at $12,000 \times \mathrm{g}$ for $10 \mathrm{~min}$. The insoluble protein was then separated using SDS-PAGE (sodium dodecyl sulfate-polyacrylamide gel electrophoresis) at $12 \%$ acrylamide and transferred to immobilon-P transfer membrane (Millipore) using a semi-dry trans-blotter (Bio-Rad, USA). The membrane was washed three times with Tris-Buffer Saline (TBS), followed by blocking using $0.5 \%$ skim milk. The membranes were incubated with the polyclonal antibody diluted with $3000 \times$ TBS buffer containing $0.5 \%$ skim milk in a shaker overnight at room temperature. The membrane was rinsed three times using TBS buffer and incubated with a secondary antibody of goat anti-rabbit IgG alkaline phosphatase (AP)-conjugate (Bio-Rad) with 3000× dilution for an hour at room temperature. The targeted CP protein was visualized with a solution mixture of BCIP (5-Bromo-4-chloro-3-Indolyl-phosphate) and NBT (nitro blue tetrazolium) (Bio-Rad, USA).

\section{Results and Discussion}

\subsection{Validation of transgenic sugarcane by PCR analysis}

To validate the transgene insertion, the DNA genome was isolated from sugarcane leaves and used for PCR analysis using F1-R1 primers pair to amplify inserted Cp gene. The PCR analysis showed amplification of the 725 bp representing the partially inserted Cp DNA fragment in both PDR and RNAi transgenic lines (Figure 1a, Figure 1b). The corresponding Cp DNA fragment was also amplified with the same molecular size in the control plasmid. The results validated the presence of the $\mathrm{Cp}$ gene in the transgenic lines used for the experiment. 


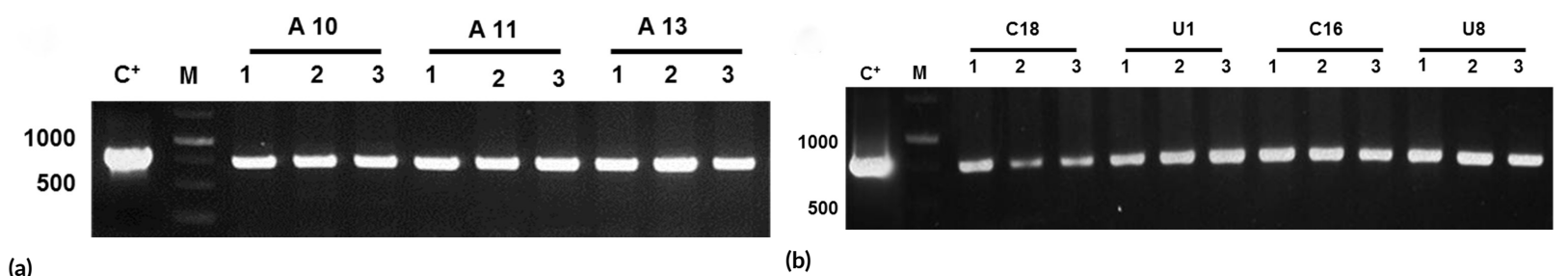

FIGURE 1 PCR amplification of $C p$ gene in transgenic sugarcane lines, size $\pm 702 \mathrm{bp}$. (a) Nine lines of PDR transgenic which three various sugarcanes (A10, A11, A13). (b) twelve lines of RNAi transgenic which four various sugarcanes (C18, U1, C16, U8) were confirmed. The number of 1, 2, 3 indicated individual plants from the same line. $C+=$ positive control; $M=D N A$ marker, $1 \mathrm{~Kb}$.

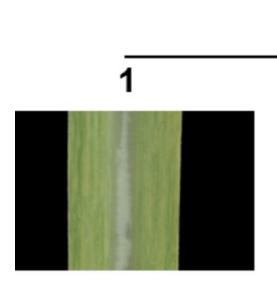

(a)

\section{A10}

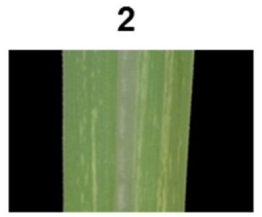

(b)

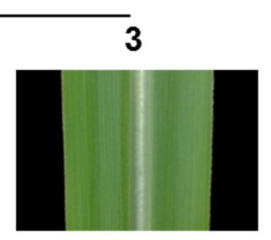

(c)

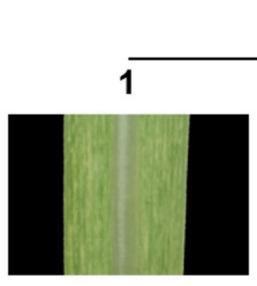

(d)

3

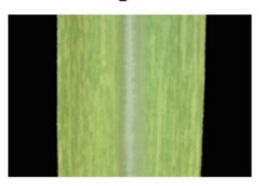

(i)

\section{A13}

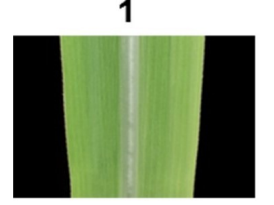

(g)

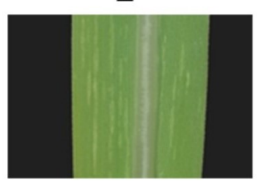

(h)

(a)

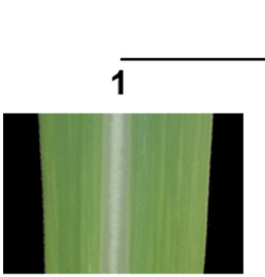

(a)
3

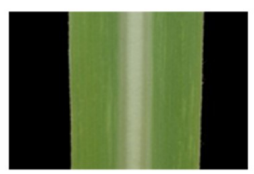

(b)

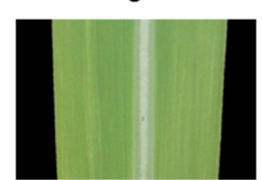

(c)

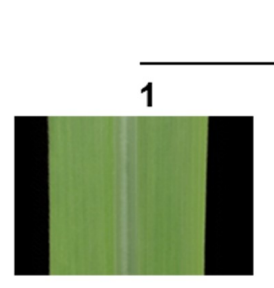

(g)

\section{C16}

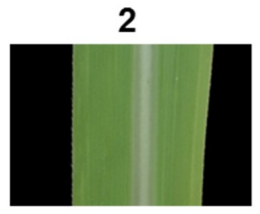

(h)

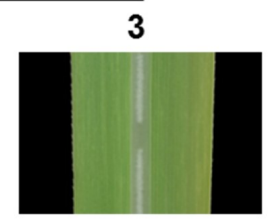

(i)

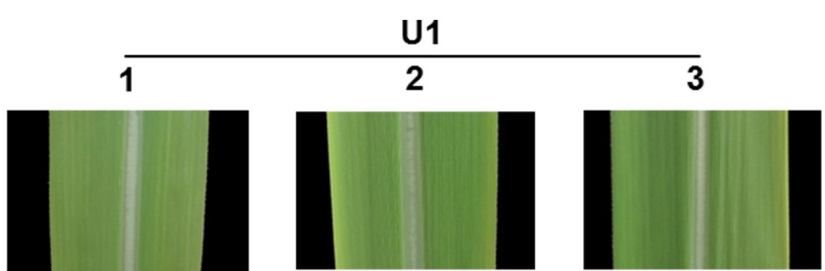

(e)

(e)

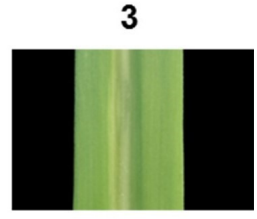

(f)

(b)

FIGURE 2 leaves of transgenic sugarcane (Saccharum officinarum L.) showing mosaic disease symptoms after inoculation from 0 to 45 dpi (a) PDR transgenic symptomatic mosaic range; Highly susceptible (a,d,e,i), susceptible (b), moderately susceptible (h), and resistant (c,f,g) (b) RNAi transgenic mosaic range; moderately susceptible (a,c,i), moderately resistant (b,d,h), resistant (e,f,g,j,k,l). The number of 1, 2, 3 indicated individual plants from the same line.

\subsection{Artificial Inoculationand symptom development}

To evaluate the viral resistance, the transgenic lines generated from PDR and RNAi methods were challenged with SCMV inoculation. As expected, symptom development was early observed at $21 \mathrm{dpi}$ and then clearly appeared at 45 dpi. Morphological symptom observation showed that among nine PDR transgenic lines, seven or $77.8 \%$ were symptomatic, but only six among 12 lines or $50 \%$ were developed the mosaic symptom in RNAi transgenic lines. Furthermore, disease assessment after artificial in- 
oculation was also determined by observation of incubation periods and mosaic symptom patterns. In terms of the incubation period (time between host infection and expression of disease symptoms), the first mosaic symptom was appeared at 26 dpi in RNAi transgenic lines but was earlier at 21 dpi in PDR transgenic lines (Table 2). According to the Cobb scale, the mosaic distribution pattern in leaves of PDR transgenic lines (Figure 2a) were grouped into $90-100 \%$, 20-30\%, and less than 5\% which predicted as highly susceptible, moderately susceptible, and resistant, respectively (Table 2). While in RNAi transgenic lines showed less mosaic distribution pattern (Figure 2b) with $11-20 \%$, 5-10\%, and less than 5\% and suggested as moderately susceptible, moderately resistant, and resistant plants respectively. Collectively, these results indicated that compared to RNAi transgenic lines, the PDR transgenic lines were more severe developed the symptom due to SCMV infection.

\subsection{Viral detection using molecular analysis}

The presence of SCMV after the viral inoculation was detected using RT-PCR and immunoblot analysis. The RTPCR analysis was directed to detect Nib DNA fragment using primer pair of F3-R3. RT-PCR analysis showed that 483 bp of Nib DNA fragment was amplified in the symptomatic leaves. The corresponding DNA fragment was not detected in lines A10.3, A13.3, U1.2, U1.3, C16.1, U8.1, U8.2, and U8.3 (Figure 3a), where the symptoms distribution pattern were found less than 5\% (Table 2). Actin DNA fragment that was used as a reference gene for normalizing the RNA content with molecular size at 568 bp was found in all examined transgenic lines (Figure $3 \mathrm{~b}$ ). These results indicated that symptomatic leaves less than 5\%, the SCMV were not found and classified as resistant plants.

To confirm the presence of viral infection in transgenic sugarcane, immunoblot analysis was conducted with a specific polyclonal antibody against CP of SCMV (Darsono et al. 2018). Immunoblot analysis revealed that the corresponding CP band with a molecular size of 37 $\mathrm{kDa}$ was found in the susceptible lines of transgenic PDR (A10.1, A10.2, A11.1, A11.2, A11.3, A13.1, A13.2) and transgenic RNAi (C18.1, C18.2, C18.3, U1.1, C16.2, C16.3). In parallel with the RT-PCR analysis, among 9 PDR transgenic lines, 7 lines (77.8\%) showed the CP band (Figure 3a), and among 12 RNAi transgenic lines, only 6 lines (50\%) appeared the corresponding protein band (Figure 3b). These molecular analyses indicated that the SCMV was detected in susceptible transgenic lines in consistent with the appearance of the symptom. Compared to RNAi transgenic lines, the PDR lines were more frequently infected by SCMV both in terms of symptom distribution and the appearance in molecular analysis.

\subsection{Discussion}

There are some techniques to produce resistant plants against viruses through transgene techniques. The most common approaches to generate the resistant transgenic plant against the virus are PDR such as overexpressing coat protein-mediated resistance (CPMR) and RNAi approach by generating siRNA (Majumdar et al. 2017). We have successfully developed transgenic sugarcane resistance to SCMV using PDR (Apriasti et al. 2018) as well as RNAi methods (Widyaningrum et al. 2021). In this study, these transgenic sugarcane lines were examined and compared to their resistances against SCMV.

Plants provide different respond for defense in the virus infection, when the interaction is compatible makes plant susceptible and cause disease. However, if the interaction is incompatible, the plant prevents virus infection and the emergence of diseases so which causes resistance (Soosaar et al. 2005). The mosaic symptoms on leaves of transgenic lines appeared at different incubation periods that might depend on the plant's response to the virus infection. The incubation period of the virus in the PDR transgenic lines was showed at $21 \mathrm{dpi}$ but was at $26 \mathrm{dpi}$ in RNAi transgenic lines (Figure 2). These results indicated that RNAi transgenic lines have delayed the appearance of the symptom and more effectively prevent virus infection.

The mosaic symptoms that appear in the leaves of sugarcane caused by SCMV infection have been proven by RT-PCR and immunoblot analysis to detect the pres-

TABLE 2 Symptoms observation after viral inoculation.

\begin{tabular}{|c|c|c|c|c|}
\hline \multicolumn{2}{|c|}{ Transgenic lines } & \multicolumn{2}{|c|}{ Symptoms observation } & \multirow[b]{2}{*}{ - Resistance } \\
\hline & & $\begin{array}{l}\text { Incubation } \\
\text { period (dpi) }\end{array}$ & $\begin{array}{l}\text { Mosaic } \\
\text { distribution } \\
\text { pattern (\%) }\end{array}$ & \\
\hline \multirow{9}{*}{ PDR } & A10.1 & 45 & 100 & Highly susceptible \\
\hline & A10.2 & 37 & 30 & Susceptible \\
\hline & A10.3 & 0 & 0 & Resistant \\
\hline & A11.1 & 26 & 100 & Highly susceptible \\
\hline & A11.2 & 26 & 90 & Highly susceptible \\
\hline & A11.3 & 45 & 2 & Resistant \\
\hline & A13.1 & 0 & 0 & Resistant \\
\hline & A13.2 & 34 & 20 & $\begin{array}{l}\text { Moderately suscep- } \\
\text { tible }\end{array}$ \\
\hline & A13.3 & 21 & 100 & Highly susceptible \\
\hline \multirow{12}{*}{ RNAi } & C18.1 & 45 & 20 & $\begin{array}{l}\text { Moderately suscep- } \\
\text { tible }\end{array}$ \\
\hline & C18.2 & 45 & 5 & Moderately resistant \\
\hline & C18.3 & 26 & 20 & $\begin{array}{l}\text { Moderately suscep- } \\
\text { tible }\end{array}$ \\
\hline & U1.1 & 34 & 10 & Moderately resistant \\
\hline & U1.2 & 0 & 0 & Resistant \\
\hline & U1.3 & 0 & 0 & Resistant \\
\hline & C16.1 & 0 & 0 & Resistant \\
\hline & C16.2 & 34 & 10 & Moderately resistant \\
\hline & C16.3 & 34 & 20 & $\begin{array}{l}\text { Moderately suscep- } \\
\text { tible }\end{array}$ \\
\hline & U8.1 & 0 & 0 & Resistant \\
\hline & U8.2 & 0 & 0 & Resistant \\
\hline & U8.3 & 0 & 0 & Resistant \\
\hline
\end{tabular}




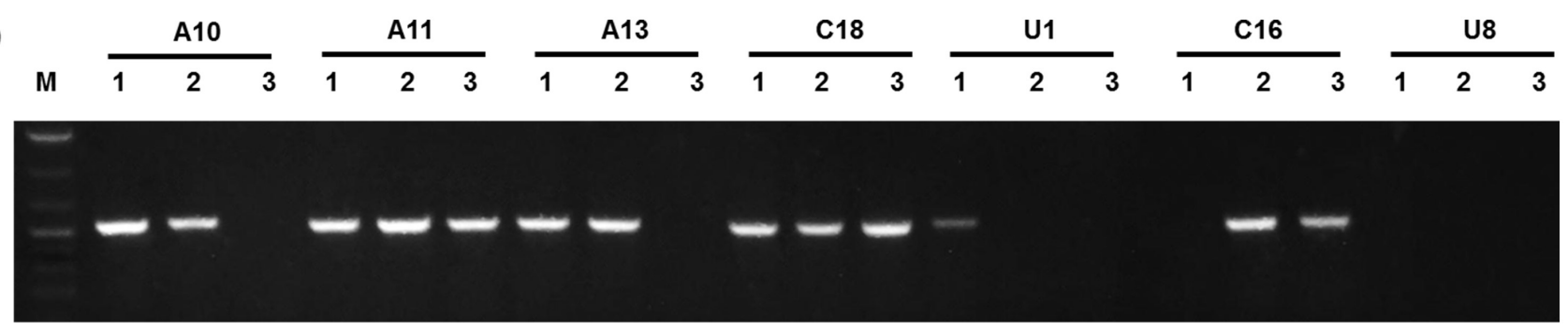

(a)

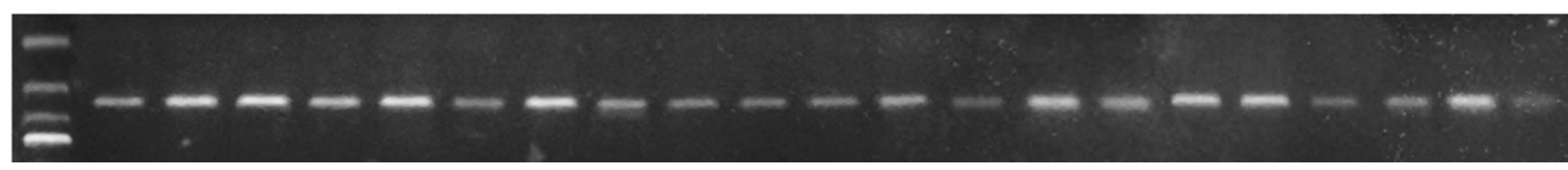

(b)

FIGURE 3 PCR amplification of Actin and Nib gene. (a) Nib gene was confirmed in infected plants. (b) Actin gene was confirmed to determines RT-PCR achievement in transgenic plants. The number of 1, 2, 3 indicated individual plants from the same line

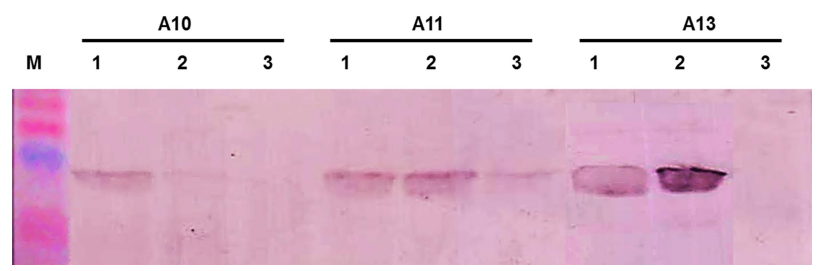

(a)
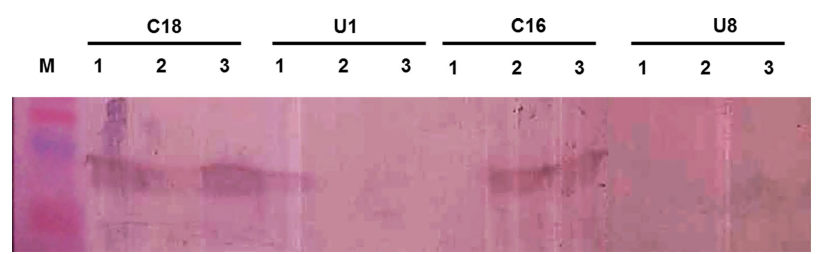

(b)

FIGURE 4 Result of coat protein expression in infected transgenic sugarcane, size $\pm 36,7 \mathrm{kDa}$. (a) seven lines of PDR transgenic was expressed viral CP (b) six lines of RNAi transgenic was expressed viral CP. The lines did not express viral $C P$, it is uninfected plants. The number of 1, 2, 3 indicated individual plants from the same line.

ence of the virus (Figure 3, Figure 4). These results implied that the virus successfully replicates and disrupts the plant defense system in the symptomatic plants. The immunoblot and RT-PCR are commonly used to detect the presence of a virus in the infected plant, such as detection of Zucchini yellow mosaic virus (ZYMV) in cucurbitaceous plants (Chen et al. 2017b), detection of SCMV in sugarcane (Addy et al. 2017), detection Citrus yellow mosaic virus (CYMV) in citrus (Kumar et al. 2018), and detection of Banana bunchy top virus (BBTV) in banana (Thomson and Dietzgen 1995). Based on molecular analysis showed that the RNAi approach targeting the gene for CP effectively produces more resistance against the SCMV infection in sugarcane compared to the PDR approach.

Upon artificial viral inoculation, the PDR and RNAi transgenic sugarcane showed mosaic symptoms incidence reach $77 \%$ and $50 \%$, respectively. Moreover, the mosaic pattern and molecular analysis indicated that the RNAi transgenic lines are more resistant than PDR transgenic lines (Figure 3, Figure 4). The ability of PDR and RNAi methods to abolish pathogen infection has been reported by some studies (Lindbo and Falk 2017). One of the possible mechanisms of the PDR transgenic plant in controlling plant viruses is delaying the symptoms. For example, the tomato transgenic plant delays symptom appearances and could recover phenotype from symptoms expression (Sengoda et al. 2012). Moreover, the PDR mechanism in a plant to block viral replication depends on the level of accumulation of CP expression (Sengoda et al. 2012; Mishra et al. 2014). The higher expression results in the higher antiviral capability to block viral replication. So that, CP-mediated resistance probably not be totally effective against virus infection. On the other hand, the RNAi transgenic plant probably reduces disease severity and virus titer. This suggestion is based on RNAi methods that develop transgenic tomato resistance against tomato TYLCV-OM. This resistance was due to the genetic virus replication is inhibited, resulting in lower virus concentration and disease development symptoms (Ammara et al. 2015). The siRNA generated by dsRNA could confer resistance to trigger gene silencing that has a direct relationship with viral replication. In a high-level expression of siRNA, the virus replication is avoided (Kumari et al. 2018). This is the new strategy to genetically engineer virus resistance to mitigate several concerns of environmental risk associated with PDR resistance.

In our study, the transgenic PDR showed highly susceptible symptoms in some lines. Meanwhile, transgenic RNAi lines showed moderately susceptible symptoms. The resistance mechanism mediated by RNAi can protect against inoculum very high because its target is specific. Protein-mediated resistance generally has a lower level of resistance, but its spectrum is wide. Furthermore, gene silencing generated by hairpin RNA (hpRNA) was reported 
as a stable gene silencing method in plants (Helliwell and Waterhouse 2005), comparing with protein-mediated resistance that the genetic stability is still unclear. Therefore, the RNAi mechanism generated siRNA was worked and indicate that this strategy could controlled virus infection at a satisfactory level.

\section{Conclusions}

The results in this study revealed that the RNAi strategy could control viral infection at a satisfactory level than the PDR strategy. Symptoms still appeared in both strategies, but the highly susceptible symptoms were showed in PDR transgenic plants. On the contrary, RNAi could decrease viral infection based on the distribution mosaic pattern and incubation period. The symptom observation has been validated by molecular analysis to confirm the presence of SCMV after viral inoculation.

\section{Acknowledgments}

This study was financially supported by Post-Graduated Research Grant (Master Thesis-Grant Number 975/UN25.3.1/LT/2020) from Ministry of Research and Technology.

\section{Authors' contributions}

BJ, WM, DA, AB designed the study. BJ, WM, DA, MS carried out the laboratory work. BJ, WM, DA, AB, MS, $\mathrm{IB}, \mathrm{HM}, \mathrm{KY}$, BS analyzed the data. BJ, WM wrote the manuscript. All authors read and approved the final version of the manuscript.

\section{Competing interests}

The author declare that they have no competing interest.

\section{References}

Addy HS, Nurmalasari, Wahyudi AHS, Sholeh A, Anugrah C, Iriyanto FES, Darmanto W, Sugiharto B. 2017. Detection and response of sugarcane against the infection of Sugarcane mosaic virus (SCMV) in Indonesia. Agronomy. 7(3). doi:10.3390/agronomy7030050.

Ammara UE, Mansoor S, Saeed M, Amin I, Briddon RW, Al-Sadi AM. 2015. RNA interferencebased resistance in transgenic tomato plants against Tomato yellow leaf curl virus-Oman (TYLCV-OM) and its associated betasatellite. Virol J. 12(1). doi:10.1186/s12985-015-0263-y.

Anurag S. 2013. Virus-induced symptoms in plants: A review of interactions between viral trafficking and RNA silencing. Philipp Agric Sci. 96(2):210-218.
Apriasti R, Widyaningrum S, Hidayati WN, Sawitri WD, Darsono N, Hase T, Sugiharto B. 2018. Full sequence of the coat protein gene is required for the induction of pathogen-derived resistance against sugarcane mosaic virus in transgenic sugarcane. Mol Biol Rep. 45(6):2749-2758. doi:10.1007/s11033-018-4326-1.

Bendahmane M, Szécsi J, Chen I, Berg RH, Beachy RN. 2002. Characterization of mutant tobacco mosaic virus coat protein that interferes with virus cell-to-cell movement. Proc Natl Acad Sci USA. 99(6):36453650. doi:10.1073/pnas.062041499.

Besong-Ndika J, Ivanov KI, Hafrèn A, Michon T, Mäkinen K. 2015. Cotranslational Coat Protein-Mediated Inhibition of Potyviral RNA Translation. J Virol. 89(8):4237-4248. doi:10.1128/jvi.02915-14.

Campo S, Gilbert KB, Carrington JC. 2016. Small RNABased Antiviral Defense in the Phytopathogenic Fungus Colletotrichum higginsianum. PLoS Pathog. 12(6). doi:10.1371/journal.ppat.1005640.

Chen H, Cao Y, Li Y, Xia Z, Xie J, Carr JP, Wu B, Fan Z, Zhou T. 2017a. Identification of differentially regulated maize proteins conditioning Sugarcane mosaic virus systemic infection. New Phytol. 215(3):11561172. doi:10.1111/nph.14645.

Chen $\mathrm{Z}$, hao Zhang $\mathrm{M}$, ping Zhou $\mathrm{X}$, xiang $\mathrm{Wu} \mathrm{J}$. 2017b. Development and detection application of monoclonal antibodies against Zucchini yellow mosaic virus. J Integr Agric. 16(1):115-124. doi:10.1016/S2095-3119(16)61416-8.

Darsono N, Azizah NN, Putranty KM, Astuti NT, Addy HS, Darmanto W, Sugiharto B. 2018. Production of a polyclonal antibody against the recombinant coat protein of the sugarcane mosaic virus and its application in the immunodiagnostic of sugarcane. Agronomy. 8(6). doi:10.3390/agronomy8060093.

Gadhave KR, Gautam S, Rasmussen DA, Srinivasan R. 2020. Aphid transmission of potyvirus: The largest plant-infecting RNA virus genus. Viruses. 12(7). doi:10.3390/v12070773.

Gao B, Cui XW, Li XD, Zhang CQ, Miao HQ. 2011. Complete genomic sequence analysis of a highly virulent isolate revealed a novel strain of Sugarcane mosaic virus. Virus Genes. 43(3). doi:10.1007/s11262-0110644-2.

Helliwell CA, Waterhouse PM. 2005. Constructs and methods for hairpin RNA-mediated gene silencing in plants. Methods Enzymol. 392:24-35. doi:10.1016/S0076-6879(04)92002-2.

Kiss L, Veres S. 2017. Study of yellow rust infection on various winter wheat genotypes. J Agric Environ Sci. 4(2):27-32. doi:10.18380/szie.colum.2017.4.2.27.

Kumar PV, Sharma SK, Rishi N, Baranwal VK. 2018. Efficient immunodiagnosis of Citrus yellow mosaic virus using polyclonal antibodies with an expressed recombinant virion-associated protein. 3 Biotech. 8(1). doi:10.1007/s13205-017-1063-4.

Kumar P SR. 2013. Current Status of Sugarcane Transgenic: an Overview. Adv Genet Eng. 02(02). 
doi:10.4172/2169-0111.1000112.

Kumari A, Hada A, Subramanyam K, Theboral J, Misra S, Ganapathi A, Malathi VG. 2018. RNAi-mediated resistance to yellow mosaic viruses in soybean targeting coat protein gene. Acta Physiol Plant. 40(2). doi:10.1007/s11738-018-2608-9.

Lindbo JA, Dougherty WG. 1992. Pathogen-derived resistance to a potyvirus: immune and resistant phenotypes in transgenic tobacco expressing altered forms of a potyvirus coat protein nucleotide sequence. Mol Plant Microbe Interact. 5(2):144-153. doi:10.1094/MPMI-5-144.

Lindbo JA, Falk BW. 2017. The impact of "coat proteinmediated virus resistance" in applied plant pathology and basic research. Phytopathology. 107(6):624-634. doi:10.1094/PHYTO-12-16-0442-RVW.

Lu B, Stubbs G, Culver JN. 1998. Coat protein interactions involved in tobacco mosaic tobamovirus cross- protection. Virology. 248(2):188198. doi:10.1006/viro.1998.9280.

Majumdar R, Rajasekaran K, Cary JW. 2017. RNA interference (RNAi) as a potential tool for control of mycotoxin contamination in crop plants: Concepts and considerations. Front Plant Sci. 8. doi:10.3389/fpls.2017.00200.

Mehta R, Radhakrishnan T, Kumar A, Yadav R, Dobaria JR, Thirumalaisamy PP, Jain RK, Chigurupati P. 2013. Coat protein-mediated transgenic resistance of peanut (Arachis hypogaea L.) to peanut stem necrosis disease through Agrobacterium-mediated genetic transformation. Indian J Virol. 24(2):205-213. doi:10.1007/s13337-013-0157-9.

Mishra R, Verma RK, Sharma P, Choudhary DK, Gaur RK. 2014. Interaction between viral proteins with the transmission of Potyvirus. Arch Phtopatholog Plant Prot. 47(2):240-253. doi:10.1080/03235408.2013.807659.

Montes C, Castro Á, Barba P, Rubio J, Sánchez E, Carvajal D, Aguirre C, Tapia E, Dell'Orto P, Decroocq V, Prieto H. 2014. Differential RNAi responses of Nicotiana benthamiana individuals transformed with a hairpin-inducing construct during Plum pox virus challenge. Virus Genes. 49(2):325-338. doi:10.1007/s11262-014-1093-5.

Muhammad T, Zhang F, Zhang Y, Liang Y. 2019. RNA Interference: A Natural Immune System of Plants to Counteract Biotic Stressors. Cells. 8(1):38. doi:10.3390/cells8010038.

Pratap D, Kumar S, Raj SK, Sharma AK. 2011. Agrobacterium-mediated transformation of eggplant (Solanum melongena L.) using cotyledon explants and coat protein gene of Cucumber mosaic virus. Indian J Biotechnol. 10(1):19-24.

Sengoda VG, Tsai WS, De La Peña RC, Green SK, Kenyon L, Hughes J. 2012. Expression of the Fulllength Coat Protein Gene of Tomato leaf curl Taiwan virus is Not Necessary for Recovery Phenotype in Transgenic Tomato. J Phytopathol. 160(5):213-219. doi:10.1111/j.1439-0434.2012.01887.x.

Sharma J, Purohit R, Hallan V. 2020. Conformational behavior of coat protein in plants and association with coat protein-mediated resistance against TMV. Braz J Microbiol. 51(3):893-908. doi:10.1007/s42770-02000225-0.

Soosaar JL, Burch-Smith TM, Dinesh-Kumar SP. 2005. Mechanisms of plant resistance to viruses. Nat Rev Microbiol. 3(10):789-798. doi:10.1038/nrmicro1239.

Srivastava AK. 2012. Sugarcane production: Impact of climate change and its mitigation. Biodiversitas. 13(4):214-227. doi:10.13057/biodiv/d130408.

Widyaningrum S, Pujiasih DR, Sholeha W, Harmoko R, Sugiharto B. 2021. Induction of resistance to sugarcane mosaic virus by RNA interference targeting coat protein gene silencing in transgenic sugarcane. Mol Biol Rep. 48(3):3047-3054. doi:10.1007/s11033021-06325-w. 